\title{
Dew, Fog and Rain Collector in a Hyper-arid Climate: Case Study in Abu Dhabi
}

\author{
Banu Sizirici, ${ }^{1, *}$ \\ ${ }^{1}$ Khalifa University of Science and Technology, Civil, Infrastructure, and Environmental Engineering Department, Abu Dhabi, P.O Box: \\ 127788, United Arab Emirates
}

\begin{abstract}
Dew condensers collect dew via thermal radiation and cooling affect without the use of external energy. The aim of this project was to design the $1 \mathrm{~m} \times 1 \mathrm{~m}$ with $30^{\circ}$ angle square funnel dew, fog and rainwater collector to calculate the dew yield in Abu Dhabi urban area. In addition, studies were conducted to determine whether the collected dew quantity is significant for practical use and to verify the cooling effect in condenser surface using temperature sensors. Aluminum was chosen as dew collector material due to its high emissivity. Square funnel was chosen as condenser shape due to easiness of the assembly and feasibility of its design. The quantity of the collected water depended on the weather condition. The average collected water was $0.016 \mathrm{ml} /$ day $\left(0.016 \mathrm{~mm} / \mathrm{m}^{2} /\right.$ day $)$. Temperature sensor analysis showed that there was a $3.5{ }^{\circ} \mathrm{C}$ temperature difference between condenser top and bottom indicating the cooling effect of square funnel shape.
\end{abstract}

\section{Introduction}

The increases in industrialization and population put heavy pressure on water supplies in our planet. In addition, there is a high demand on the energy-efficient and environmentally-friendly methods to obtain water for house-hold and agriculture purposes. Since the UAE does not have any surface waters, the main sources of water are seawater and groundwater. However, groundwater is of poor quality, and the desalination of the sea water is quite expensive. Therefore, alternative water production systems are in demand. Dew has been proposed as an alternative water resource in arid to subtropical regions. It helps plants and animals thrive in arid and semi-arid climates. Dew is atmospheric water vapor which condenses on surfaces cooler than dew point temperature (the temperature at which water droplets form). Radiation ( the loss of heat to the sky) leads to cooling and this process is the main contributor to the formation of dew droplets [1]. Moreever, meteorological conditions such as ambient air temperature, relative humidity, wind speed, cloud cover, and sky radiation also play significant roles in condensation process. The dew formation is notable during nighttime with a clear sky due to high radiant heat loss from the exposed surface. When the warmer moist air pass over the cool surface, the air is cooled and the water vapor condense into droplets on the surfaces [2]. Dew collectors can collect not only dew but also rain water. There are two types of dew water collectors: radiative (passive) and active dew water condensers. Radiative condensers rely on collecting dew water via radiative exchange with sky which results zero energy input [2]. Dew collectors have been placed upon the sloped roofs of the buildings, terraces, and directly on the ground[3-6]. The maximum theoretical dew condensation is limited to $0.8 \mathrm{~mm}$ (i.e. $0.8 \mathrm{~L} . \mathrm{m}^{-2}$ ) per night [7]. According to the available radiative energy for condensation, the maximum dew water yield is about $0.3-0.6 \mathrm{~L} /$ day $/ \mathrm{m}^{2}$ of surface area in arid and semi-arid climates [8-10]. The maximum dew yield measured was almost $0.6 \mathrm{~L} / \mathrm{m}^{2} /$ day [11]. Dew collectors in humid climates showed lower dew water yields. The collector in a grassland area in the Netherland collected $0.19 \mathrm{~L} /$ day $/ \mathrm{m}^{2}$ water [12]. Dew collector in humid tropical island in French Polynesia collected $0.23 \mathrm{~L} / \mathrm{day} / \mathrm{m}^{2}$ water [13]. Another collector in an agricultural area close to an urban site in SainteAnnede-Bellevue, QC, Canada collected $0.37 \mathrm{~L} / \mathrm{day} / \mathrm{m}^{2}$ water [2]. Plain, uninsulated, and corrugated galvanized iron roofs yielded $113.5 \mathrm{~L}$ water $(6.3 \mathrm{~mm})$ in Kothara, India [4]. A dew harvesting system collected $0.28 \mathrm{~L} / \mathrm{m}^{2} /$ day of dew compared to $0.17 \mathrm{~L} / \mathrm{m}^{2} /$ day of rainfall in Morocco [5]. In this project, we designed $1 \mathrm{~m}^{2}$ planar dew, fog and rainwater collector to calculate the dew water yield and to determine the cooling effect in dew collector using temperature sensors. The UAE's climate is hot and hyper arid, and humidity can reach up to $90 \%$ with low wind speed which are in favor of dew condensation. Square funnel shape was chosen as dew collectors' shape. The quantity and frequency of collected dew water were measured to determine if the quantity is significant for practical use.

\section{Materials and Methods}




\subsection{Weather and Geography}

The city of Abu Dhabi is located on the Arabian Peninsula between latitudes $24^{\circ}$ and $26^{\circ}$ North and between $54^{\circ}$ and $38^{\circ}$ East with $7 \mathrm{~m}$ of altitude. The dew collector prototypes were built and tested in Khalifa University, Abu Dhabi Campus $\left(24^{\circ} 26^{\prime} 52^{\prime \prime} \mathrm{N}\right.$ and $\left.54^{\circ} 23^{\prime} 41^{\prime \prime} \mathrm{E}\right)$, which is $15 \mathrm{~km}$ away from the sea. The location was an urban area and dew collector was set on the stone pavement. Abu Dhabi is considered to have a desert climate. Köppen and Geiger classified this climate as hot dessert climate (BWh: B: dry climate, BW: arid climate, h: warm) [14]. The average annual temperature is $26.8{ }^{\circ} \mathrm{C}$, and the average annual rainfall is $75 \mathrm{~mm}$ in Abu Dhabi. The greatest amount of precipitation occurs in February with an average of 29 $\mathrm{mm}$. There are two main seasons: winter lasts from November to March (average $26^{\circ} \mathrm{C}$ during the daytime and $15^{\circ} \mathrm{C}$ during the nighttime), and summer lasts from April to September. Summers are very hot, and temperatures can rise to about $48^{\circ} \mathrm{C}$ with humidity levels reaching as high as $90 \%$ as shown in Table 1 . The annual average pan evaporation is around $7.5-8 \mathrm{~mm}$ /day which makes the area hyper arid $[15,16]$.

Meteorological data such as ambient temperature, relative humidity, wind speed, wind direction, and cloud cover were obtained from a nearby weather station located $7 \mathrm{~km}$ northeast of the campus to assess the influence of local meteorological conditions on dew and fog formation as shown in Table 1 . In addition, humidity and temperature sensors connected with ARDUINO with data logger were placed on top of the dew collector to collect the real time ambient temperature and humidity data with the $\pm 5 \%$ accuracy.

Table 1. Weather data in Abu Dhabi in 2018

\begin{tabular}{|c|c|c|c|c|}
\hline Month & $\begin{array}{c}\text { Av. } \\
\text { Temperature } \\
\mathbf{0}^{\mathbf{C}}\end{array}$ & $\begin{array}{c}\text { Av. } \\
\text { Humidity } \\
\mathbf{\%}\end{array}$ & $\begin{array}{c}\text { Av. } \\
\mathbf{W i n d} \\
\mathbf{k m} / \mathbf{h}\end{array}$ & $\begin{array}{c}\text { Av. } \\
\text { Rainfall } \\
\mathbf{m m}\end{array}$ \\
\hline January & 20 & 66 & 13.8 & 9.1 \\
\hline February & 21 & 66 & 15 & 4.2 \\
\hline March & 23 & 64 & 14.7 & 8.8 \\
\hline April & 27.5 & 59 & 13.5 & 6.5 \\
\hline May & 31.5 & 57 & 13 & 0 \\
\hline June & 33 & 62 & 13.7 & 0 \\
\hline July & 35.1 & 61 & 13.7 & 0 \\
\hline August & 35.6 & 60 & 13.9 & 0 \\
\hline September & 33.8 & 63 & 13.3 & 24.8 \\
\hline October & 30.9 & 63 & 12.8 & 22.8 \\
\hline November & 26.7 & 61 & 13.5 & 23.7 \\
\hline December & 22.5 & 66 & 13.6 & 23.4 \\
\hline
\end{tabular}

\subsection{Condenser surface design}

Square funnel design $(1 \mathrm{~m} \times 1 \mathrm{~m})$ with 30 degree angle was chosen due to easiness of the assembly, feasibility of its design and commonality. The square funnel (inverted pyramid) shape of the dew collector and its effect on water collection capacity have been studied in different studies. A square funnel dew collector with an angle of $30^{\circ}$ in a grassland area in the Netherland collected $20 \%$ more water than a standard $1 \mathrm{~m}^{2}$ planar dew collector [12]. Another study showed that a funnel-shaped condenser with a half-angle of $30^{\circ}$ showed $40 \%$ more water than $1 \mathrm{~m}^{2}$ and $30^{\circ}$ inclined planar condenser [17, 18]. The shape of funnel reduced the flow of warm air and held the heavier cold air at the bottom. Also the square funnel design protected condenser from the wind and shielded from infrared emission of the lower layers of the atmosphere $[12,13]$. Another study stated that the "best" tilt angle for the passive dew drop recovery was $30^{0}$ due to the gravity flow of the dewdrops[17, 19].

\subsection{Material Selection for the Condenser Surface}

Aluminum 1060 (aluminum content of 99.1\%) was used as condenser material which has high corrosion resistance and workability [20]. Aluminum has been selected because it is cheap, strong (density: $2.7 \mathrm{~g} / \mathrm{cm} 3$ ), high in emissivity (0.03-0.77 depend on surface) and thermal conductivity $(237 \mathrm{~kW} /(\mathrm{m} . \mathrm{K}) @ 300 \mathrm{~K})$; it can be folded and machined easily: it is readily available in the local market. Square funnel was chosen as dew condenser shape. Underside of the aluminum condenser was insulated with the white coating to prevent heat gain from the ground below as shown in Figure 1. Another study tested three materials (aluminum, glass and polyethylene) for dew condenser surface, and found that aluminum had the highest dew yield because its polished surface enables dew water easily slide along the surface [21]. Dew water was collected in the plastic bottles connected to the tip of the condenser, and the volumes were measured each morning at 08:00 a.m at the local time.

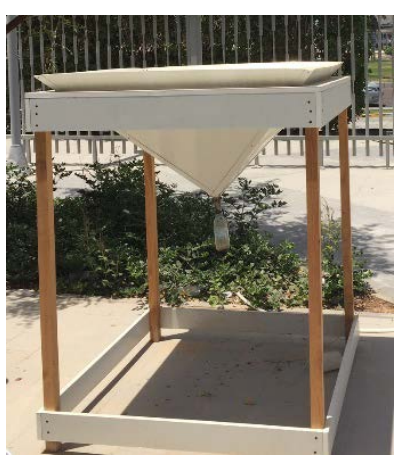

Figure 1. Dew, fog and rain collector

\subsection{Condenser surface temperature}

Cooling effect of the condenser surface were analyzed using temperature sensors. 16 DHT11 temperature and humidity sensors (4 sensors for each side) were placed at the inner side of the condenser surfaces with different elevations as shown in Figure 2. Sensor 1 was placed at the top of the the condenser and sensor 4 was placed at the bottom/tip of the condenser. DHT11 is a basic temperature and humidity sensor which uses capacitive humidity sensor and a thermistor to measure nearby air. The sensor sends digital signal on the data pin ( $1 \mathrm{~s}$ and $0 \mathrm{~s}$ ) and it collects new data every 2 seconds [22]. DHT11 
sensors were programmed to collect daily data. Arduino compatible ESP8266 based board with a microcontroller (Wi-Fi module) was used as an access point to allow receiving and sending data instantaneously (receive from: DHT11, send to: ThingSpeak.com). Wi-Fi module sent the data to the website Thingspeak to be viewed online. Thingspeak.com is an "open data platform that allows its users to easily document and share the data collected" [23]. The data was collected with 10-minute intervals from $7.00 \mathrm{pm}$ to 7.00 am twice a week from September 1, 2017 to May 1, 2018.

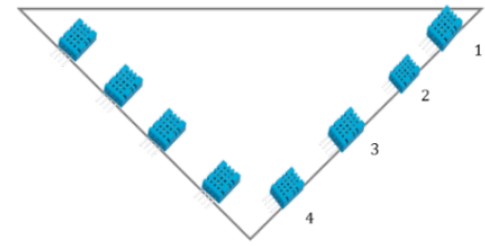

Figure 2. Positions of the sensors on the condenser surface

\section{Results and Discussion}

\subsection{Temperature analysis}

The weekly average temperature obtained from the sensors showed that there were $0.98{ }^{\circ} \mathrm{C}$ to $3.3{ }^{\circ} \mathrm{C}$ temperature differences between the top (sensor 1) and the bottom of the condenser (sensor 4 ), and $0.2{ }^{\circ} \mathrm{C}$ to $1.4{ }^{\circ} \mathrm{C}$ temperature difference between top of the condenser and ambient temperature as shown in Figure 3.

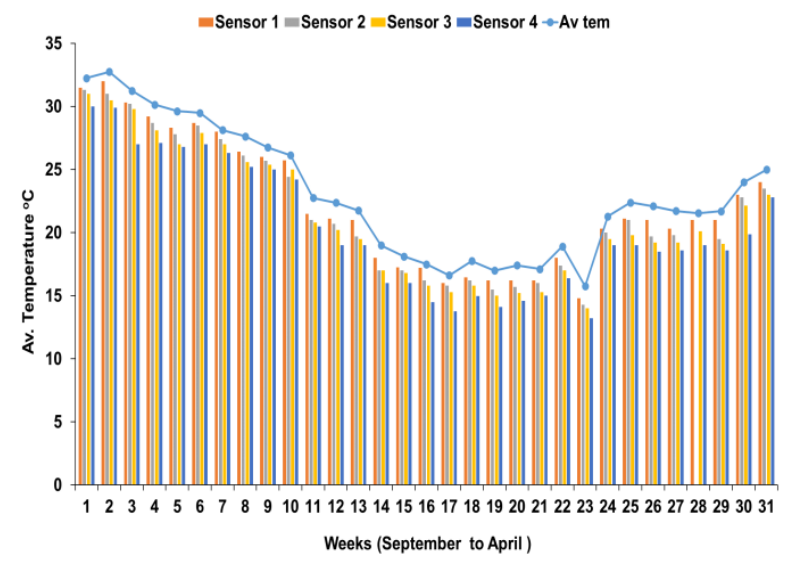

Figure 3. Weekly average measured temperatures by the sensors together with the ambient temperatures.

Hourly data revealed that cooler temperature values were observed at sensor 4 . The maximum temperature differences were observed between $1.00 \mathrm{pm}$ and $5.00 \mathrm{pm}$ as shown in Figure 4.

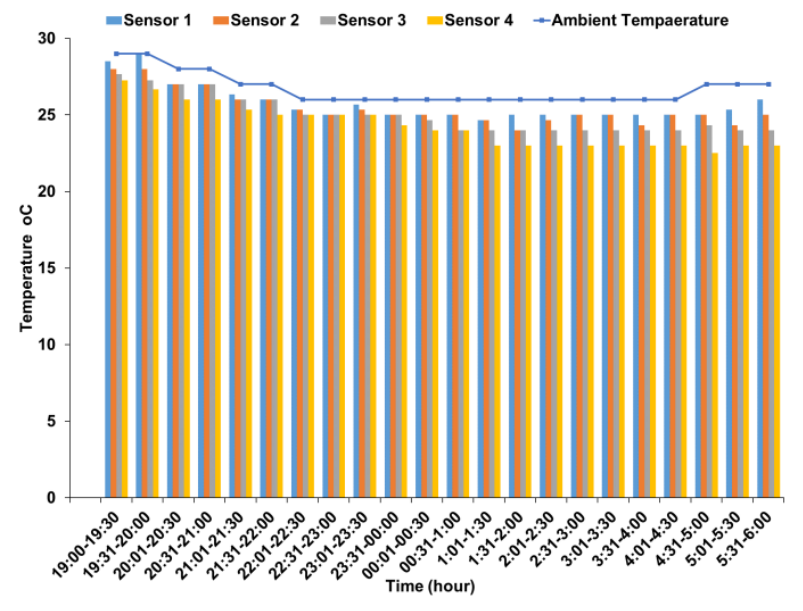

Figure 4. Hourly temperature sensor data together with ambient temperature recorded for April26, 2018

According to a study, plain, uninsulated, corrugated, and galvanized iron roofs yielded maximum $2{ }^{\circ} \mathrm{C}$ of cooling temperature, while a condenser that was thermally insulated had maximum $3.4-3.7^{\circ} \mathrm{C}$ of cooling temperature in North West India [2]. Another study reported that on the nights when large amounts of dew condensed, the condenser surface would cool below the ambient temperature by $4{ }^{\circ} \mathrm{C}$ or more [10]. Our results confirm the cooling effect of the square funnel. In addition, it is in parallel with the results of computational fluid dynamics simulations performed in other studies. According to these simulations air gets cooler inside the funnel and the cooler air slips to the center of funnel. [17, 24].

\subsection{Water collection}

The analysis of the data collected during a one-year study showed that the dew occurred from September to April. Dew, rain and fog events occurred approximately 100 days in 2018 , but water collection occurred only 51 days because not all droplets formed on the condenser slid to the collection container. Similar results were reported in other studies as well $[8,10,11,25]$. The dew events were observed when the relative humidity was at least $80 \%$ or more as shown in Figure 5.

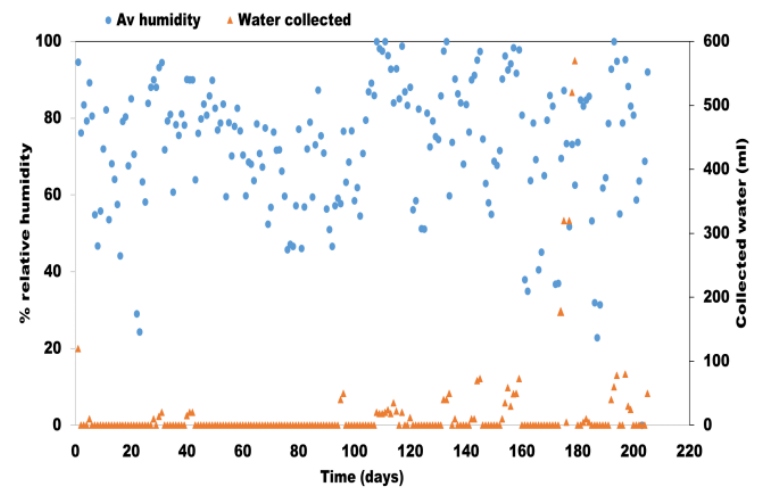

Figure 5. Water collection from September to April 2018

Similarly, a study in the southwest Morocco showed that when the relative humidity was between $74 \%$, and 
$92 \%$, water condensed on the condenser surface [10]. The average collected water was $0.016 \mathrm{ml} /$ day $(0.016$ $\mathrm{mm} / \mathrm{m}^{2} /$ day). The daily dew yield in Jerusalem was 0.2 $\mathrm{mm}$ on average with a maximum of $0.6 \mathrm{~mm}$ and the dew yield in Zadar and Beirut was $0.04 \mathrm{~mm}$ on average [18]. As another study stated, the water collection per day for dew collectors is relatively low and difficult to predict [2]. Some other studies stated that following effects could lead to lower water collection such as:

1. Buildings in urban areas obstruct the sky view resulting in higher nocturnal temperatures which lead to urban heat island effect and inhibit dew formation [26-28].

2. During warmer months, urban areas have lower relative humidity than nearby rural areas, therefore less humidity correlated with urban heat island effects could reduce dew formation [29, 30].

3. Increased evaporation in urban areas due to urban heat island effect inhibits the condensation which leads to less dew formation [31].

4. Increased atmospheric pollution in urban environment may inhibit the atmospheric transmittance and leads to less dew formation $[2,18$, 32]

5. Dust accumulation is a serious issue in Abu Dhabi, and the accumulation of the dust on the condenser surface may inhibit the gravity slide of the formed dew to the collection container [33].

\section{Conclusion}

A passive dew, fog, and rain water collector made from square-funnel-shaped aluminum was used as an additional water source in Abu Dhabi. The temperature sensors placed on the condenser with different elevations revealed that there was a maximum of $3.5{ }^{\circ} \mathrm{C}$ temperature difference between the top and bottom sensors and a maximum of $1.4{ }^{\circ} \mathrm{C}$ difference between the ambient temperature and the top surface of condenser indicating the cooling effect of the condenser. One-year data collection showed that the dew occurred in 100 days in which 51 of them yielded water collection. The average collected water was $0.016 \mathrm{ml} /$ day $(0.016$ $\mathrm{mm} / \mathrm{m} 2 /$ day). The lower dew yields might be as a results of urban heat island effect. To be able to make dew water as a useful supplementary water resource in Abu Dhabi, more analysis is necessary related to the shape, size, and material of the dew collector as well as the location where it should be placed.

\section{References}

1. Middleton, W.E., History of the Theories of Rain and other forms of precipitation. (1966).

2. Khalil, B., et al., A review: dew water collection from radiative passive collectors to recent developments of active collectors. Sustainable Water Resources Management, (2016). 2(1): p. 71-86.
3. Beysens, D., et al., Collecting dew as a water source on small islands: the dew equipment for water project in Bis evo (Croatia). Energy, (2007). 32(6): p. 1032-1037.

4. Sharan, G., D. Beysens, and I. MilimoukMelnytchouk, A study of dew water yields on Galvanized iron roofs in Kothara (North-West India). Journal of Arid Environments, (2007). 69(2): p. 259-269.

5. Clus, O., et al., Dew, fog and rain water collectors in a village of S-Morocco (Idouasskssou). Desalination and Water Treatment, (2013). 51(1921): p. 4235-4238.

6. Sharan, G., et al., A very large dew and rain ridge collector in the Kutch area (Gujarat, India). Journal of hydrology, (2011). 405(1): p. 171-181.

7. Monteith, J.L., Dew. Quarterly Journal of the Royal Meteorological Society, (1957). 83(357): p. 322-341.

8. Muselli, M., et al., Dew and rain water collection in the Dalmatian Coast, Croatia. Atmospheric Research, (2009). 92(4): p. 455-463.

9. Maestre-Valero, J., et al., Comparative analysis of two polyethylene foil materials for dew harvesting in a semi-arid climate. Journal of hydrology, (2011). 410(1): p. 84-91.

10. Lekouch, I., et al., Rooftop dew, fog and rain collection in southwest Morocco and predictive dew modeling using neural networks. Journal of hydrology, (2012). 448: p. 60-72.

11. Berkowicz, S.M., et al., Urban dew collection under semi-arid conditions: Jerusalem. (2004).

12. Jacobs, A.F.G., B.G. Heusinkveld, and S.M. Berkowicz, Passive dew collection in a grassland area, The Netherlands. Atmospheric Research, (2008). 87(3): p. 377-385.

13. Clus, O., et al., Study of dew water collection in humid tropical islands. Journal of hydrology, (2008). 361(1): p. 159-171.

14. Peel, M.C., B.L. Finlayson, and T.A. McMahon, Updated world map of the Köppen-Geiger climate classification. Hydrology and earth system sciences discussions, (2007). 4(2): p. 439-473.

15. Ministry of Presidential Affairs, N.C.o.M. (2018) [cited 2018 25/5/2018]; Available from: https://www.ncm.ae/en/index.html\#!/Radar_UAE_A D ReflectivityAD-DP/26.

16. data.org, c. 2018 25/05/2018]; Available from: https://en.climate-data.org/asia/united-arabemirates/abu-dhabi/abu-dhabi-3217/.

17. Clus, O., et al., Comparison of various radiationcooled dew condensers using computational fluid dynamics. Desalination, (2009). 249(2): p. 707-712.

18. Tomaszkiewicz, M., et al., Dew as a sustainable non-conventional water resource: a critical review. Environmental reviews, (2015). 23(4): p. 425-442.

19. Beysens, D., et al., Using radiative cooling to condense atmospheric vapor: a study to improve 
water yield. Journal of hydrology, (2003). 276(1): p. $1-11$.

20. Avallone, E., I. Baumeister, and A. Sadegh, Marks' Standard Handbook for Mechanical Engineers. 10. (2006): New York: McGraw-Hill.

21. Alnaser, W. and A. Barakat, Use of condensed water vapour from the atmosphere for irrigation in Bahrain. Applied Energy, 2000. 65(1): p. 3-18.

22. Adafruit Industries, U.f.D.e.a.k. DHT11 basic temperature-humidity sensor + extras ID: 3862017 [cited 2017 25/12/2017]; Available from: https://www.adafruit.com/product/386.

23. ThingSpeak, , The open IoT platform with MATLAB analytics. 2018.

24. Edouard Cabay, E.P., Dew harvesting devices and their application in architecture. (2014), Ecole Spéciale d'Architecture, Paris.

25. Muselli, M., D. Beysens, and I. Milimouk, $A$ comparative study of two large radiative dew water condensers. Journal of Arid Environments, (2006). 64(1): p. 54-76.

26. Spronken-Smith, R. and T. Oke, Scale modelling of nocturnal cooling in urban parks. Boundary-Layer Meteorology, 1999. 93(2): p. 287-312.

27. Kim, Y.-H. and J.-J. Baik, Maximum urban heat island intensity in Seoul. Journal of applied meteorology, (2002). 41(6): p. 651-659.
28. Gedzelman, S., et al., Mesoscale aspects of the urban heat island around New York City. Theoretical and Applied Climatology, (2003). 75(12): p. 29-42.

29. Unkašević, M., O. Jovanović, and T. Popović, Urban-suburban/rural vapour pressure and relative humidity differences at fixed hours over the area of Belgrade city. Theoretical and Applied Climatology, (2001). 68(1-2): p. 67-73.

30. Fortuniak, K., K. Kłysik, and J. Wibig, Urban-rural contrasts of meteorological parameters in Łódź. Theoretical and applied climatology, (2006). 84(1-3): p. 91-101.

31. Kuttler, W., et al., Urban/rural atmospheric water vapour pressure differences and urban moisture excess in Krefeld, Germany. International Journal of Climatology: A Journal of the Royal Meteorological Society, (2007). 27(14): p. 2005-2015.

32. Beysens, D., et al., Measurement and modelling of dew in island, coastal and alpine areas. Atmospheric Research, (2005). 73(1-2): p. 1-22.

33. Sizirici, B., Modified biosand filter coupled with a solar water pasteurizer: Decontamination study. Journal of Water Process Engineering, (2018). 23: p. 277-284. 